\title{
The role of diasporas and social media in student migration
}

\author{
Aleksandr A. Gusakov ${ }^{1 *}$ \\ ${ }^{1}$ Peoples' Friendship University of Russia (RUDN University), Moscow, Russia \\ "Email: gusakov-aa@rudn.ru
}

\begin{abstract}
The article analyses the role of ethnic diasporas and digital social media in student migration. A survey of students from 18 countries who study at RUDN University was conducted. This university is the most international in the Russian Federation because students from more than 160 countries learn there. To analyse the number of representatives of diasporas in social media, data on the number of expats of these 18 countries were obtained from Facebook. Since Facebook's data on the number of expats are not always accurate, they were compared with statistical data on the balance of migration to Russia from these countries and data on the number of students of these countries in Russian universities. When deciding to move to another country for education, young people can get valuable information from members of the diaspora who have graduated from universities there. A model of the student migration process has been developed by clarifying the composition of the migration infrastructure in the Carling migration model. The findings confirm the vital role of the presence of diasporas in social media to reduce the risks of student migration.
\end{abstract}

Keywords: Student migration, Student migration model, Social media, Diasporas in social media.

\section{INTRODUCTION}

The concept of "student migration" implies studying in another country to obtain a qualification (diploma of higher education), that is, long-term mobility. Long-term international mobility can bring significant returns to the labour market [1]. According to UNESCO forecasts, the number of international students worldwide by 2025 may exceed 7 million people [2]. A few rationales drive high education internationalisation: political, economic, academic, and sociocultural [3]. International academic mobility in Europe is based on implementing the Bologna Process. The availability of various programs that support international student mobility facilitates decisions about studying in another country.

Along with the processes of globalisation, this has led to the fact that "internationalisation is an important current characteristic and goal of most students" [4]. The existence of ethnic, religious and other diasporas and social media facilitates obtaining support both in the form of counselling and for adaptation in a new country [5]. The purpose of this study is to test the hypothesis about the influence of social media and diasporas on the decision-making of international students to study in Russia and to build a decision-making model for student migration.

\section{METHODOLOGY}

We used a structured survey among RUDN University students about the role of social media information in their decision-making about studying in Russia and how important it was for them to have an ethnic diaspora in the country of study. The anonymous survey was conducted in the fall semester of the 20202021 academic year among undergraduate students of different faculties. 84 students from 18 countries took part in the survey. The survey was attended by representatives of countries from which the number of students studying in Russia is growing, such as China, Tajikistan and Kazakhstan. Also, students from regions relatively far from Russia have significantly fewer students. It is essential to consider students' opinions from the different world areas because when they decide, the factor of proximity to Russia has different meanings. For example, El Salvador, Laos, Paraguay, Equatorial 
Guinea and others. To estimate the size of ethnic diasporas of all countries, students from which took part in the survey, data from state migration statistics were used. These data were obtained from the online database of the Federal State Statistics Service of Russia by forming a sample from the data marts. The assessment of the presence of members of the ethnic diasporas of these countries was made using Facebook data. The estimate of the number of expats on Facebook may differ significantly from actual data. Therefore, another source of information about the representatives of these countries in Russia was used. From the annually published report on the export of Russian education, data on the number of students from 18 countries in Russian universities in the 2018-2019 academic year were selected.

\section{RESULTS AND DISCUSSION}

\subsection{The role of social media and ethnic diasporas in student migration}

According to the network theory of migration, "migrant networks are the sets of interpersonal links that connect migrants, former migrants and non-migrants in places of origin and destination through the ties of kinship, friendship and the general community" [6]. The establishment of new contacts is facilitated by the presence of common ethnic, religious and linguistic roots, in other words, belonging to the diaspora. The presence of migrant networks increases information flows between participants, reducing the risks of moving to another country [7]. For example, a study on highly skilled migrants from Indonesia showed that they use social media to get information before choosing a destination country. They use Facebook to contact their friends and colleagues in the destination country [5]. In the last decade, the spread of digital social media has led to a simplification of finding new contacts, the emergence of new ways of communication, and a significant reduction in the cost and speed of interaction. Free wireless networks contribute to illiterate users exchanging voice messages even in countries with a low average literacy level. When school graduates analyse the possibilities of studying in another country, they start looking for information on the Internet and social networks. To find out detailed information about living conditions, the availability of the usual national food, etc., young people usually use social networks to find contacts in these universities and the country.

To test the hypothesis about the influence of social media and diasporas on the decision to study in Russia in the fall semester of the 2020-2021 academic year, a survey was conducted among international students who

Table 1. The importance of social media and the presence of a diaspora, in per cent

\begin{tabular}{|l|c|c|c|}
\hline \multicolumn{1}{|c|}{ Question } & $\begin{array}{c}\text { Important/ } \\
\text { Very important }\end{array}$ & $\begin{array}{c}\text { Perhaps not } \\
\text { important / Not } \\
\text { important at all }\end{array}$ & No such benefit \\
\hline $\begin{array}{l}\text { How important the information on social media was } \\
\text { for you when choosing a country and university for } \\
\text { study }\end{array}$ & 67.9 & 10.7 & 21.4 \\
\hline $\begin{array}{l}\text { How important the information on social media was } \\
\text { for choosing the country in which you would like to } \\
\text { work after training }\end{array}$ & 64.4 & 14.2 & 21.4 \\
\hline $\begin{array}{l}\text { How important the information you found on social } \\
\text { media was for you when adapting to the university }\end{array}$ & 60.8 & 14.2 & 10.7 \\
\hline $\begin{array}{l}\text { How important the information you found on social } \\
\text { media was for you to adapt to the country in which } \\
\text { you study (living conditions, purchases, transport, } \\
\text { other) }\end{array}$ & 71.5 & 14.2 & 25 \\
\hline $\begin{array}{l}\text { How important is the presence of your diaspora in } \\
\text { the country in which you would like to study }\end{array}$ & & & \\
\hline $\begin{array}{l}\text { How important is the presence of your diaspora in } \\
\text { the country where you plan to work after } \\
\text { graduation }\end{array}$ & 60.8 & 14.2 & 25 \\
\hline
\end{tabular}


study at RUDN University. Currently, the Russian Federation is in seventh place globally regarding the number of international students [8]. The total number of full-time international students in Russian universities increased from 108.7 thousand people in the 2009/2010 academic year to 282.3 thousand in the 2018/2019 academic year. Thus, the share of international students of all forms of education increased over the same period from $2.36 \%$ to $8.54 \%$ of the total number of students of Russian universities [8].

Currently, out of 34 thousand students of all forms of study at RUDN, more than 10 thousand are international students from 160 countries. This is the most international Russian university. Over the 60 years of the existence of the RUDN, tens of thousands of young people from 170 countries have become graduates [9]. In some countries, peculiar "diasporas" of RUDN graduates have formed. The university has a scholarship program for the winners of its open Olympiads. He holds the 124th position on the internationalisation of QS WUR.

The study was conducted according to a formalised questionnaire. 84 students from 18 countries took part in the survey. The distribution of students who participated in the survey by country: China $(16,7 \%)$, Tajikistan $(14,3 \%)$, Kazakhstan (10,7\%), Afghanistan and
Uzbekistan (7,1\%), Bosnia and Herzegovina, the Congo Democratic Republic of El Salvador, Equatorial Guinea, Ethiopia, Greece, Iraq, Laos, Mongolia, Montenegro, Paraguay, Vietnam - (3,6\% each), Comoros $(1,2 \%)$.

The results of the survey are presented in the following. Students' answers to questions related to social media and the availability of a diaspora in the host country are summarised in Table 1 . The survey participants could choose from the answers "very important", "is important", "no such benefit", "perhaps not important", "not important at all".

The study results show that social networks have been an essential source of information about the university and the country they plan to study for students from different countries and regions of the world. They also believe that social media will help them find a job after graduation. At the same time, $64.3 \%$ of the students who took part in the study would like to work in their home country. Another $28.6 \%$ will look for work in the country where they are currently studying, and $7.1 \%$ - in third countries (as a rule, students meant developed countries). More than $60 \%$ of the responses confirm that information on social media helped them adapt faster at university, and for $71.5 \%$ of respondents, social media helped them adapt to a new country. More than $60 \%$ prefer to study

Table 2. The number of emigrants, migrants and international students in Russia, in people

\begin{tabular}{|c|c|c|c|}
\hline Country & Facebook data (2021) & $\begin{array}{l}\text { The balance of migration } \\
\text { flows (2001-2020) }\end{array}$ & $\begin{array}{l}\text { Students in Russian } \\
\text { university (2018/2019) }\end{array}$ \\
\hline Afghanistan & - & 4246 & 1600 \\
\hline Bosnia and Herzegovina & - & 301 & 206 \\
\hline China & 7500 & 8638 & 36466 \\
\hline Congo, democratic republic of the & 2100 & 168 & 495 \\
\hline Comoros & - & 16 & 26 \\
\hline El Salvador & 200 & 18 & 84 \\
\hline Equatorial Guinea & - & 25 & 252 \\
\hline Ethiopia & 1500 & 77 & 95 \\
\hline Greece & - & 1437 & 461 \\
\hline Iraq & - & 2033 & 5070 \\
\hline Kazakhstan & - & 493566 & 43318 \\
\hline Laos & - & 140 & 218 \\
\hline Mongolia & - & 319 & 3565 \\
\hline Montenegro & - & 8 & 78 \\
\hline Paraguay & - & 1 & 41 \\
\hline Tajikistan & - & 315633 & 17241 \\
\hline Uzbekistan & - & 372316 & 18557 \\
\hline Vietnam & 51800 & 11351 & 4749 \\
\hline
\end{tabular}

Source: Compiled by the authors from Facebook [11], [8] 
and work in countries with a diaspora to relate to themselves (ethnic, religious or linguistic).

Students will be able to find their former compatriots in another country more easily if there are ethnic diasporas in it and their members use social media. To assess whether ethnic diasporas existing in Russia are represented in social media, Facebook (https://www.facebook.com) data was used, classifying some users as expats. Unfortunately, Facebook data does not allow us to estimate the number of expats from all countries that we are interested in. The representativeness of Facebook data is not high enough. This is due to the penetration rate of Facebook apps for different age groups and genders in the country of the expat's previous residence and destination country. This may also be due to the incorrect models that Facebook uses to classify users [10]. To increase representativeness in our study, we also used data from the Federal State Statistics Service of the Russian Federation (Rosstat). Data on the balance of migration flows from different countries to Russia in 2001-2020 were obtained from Rosstat data marts [11]. The report on the export of Russian education [8] makes it possible to estimate the number of international students in Russia. Data from these sources ([11], [8]) are presented in Table 2. This table shows data for 18 countries, students from which took part in the survey. Many international students who study in Russia use the popular social network VKontakte. However, this application does not provide an opportunity to estimate the number of expats in Russia from among its users.

Based on the data in Table 2, it can be concluded that residents of most countries whose students took part in the study will be able to find their compatriots in Russia, including on social media. Social media are transforming migration networks and thereby lowering the threshold for migration [12]. Their compatriots, graduates of Russian universities who, after completing their studies in Russia, can return to their homeland or move to a third country, will also be able to provide them with advisory assistance. The migration does not always mean leaving the place of permanent residence and settling in another place permanently but instead circulating between different locations [13]. Student international migration confirms this statement since students often graduate with a bachelor's degree, not in their homeland and then move to a third country to study for a master's degree.

It should be noted that connections with immigrants from their country are meaningful and the opportunity to communicate with members of linguistic and religious diasporas. This is because residents of small countries and territories see the differences between their nation and other nations and nationalities when they live at home. Far from the home country, these differences may not matter so much if there are other unifying factors, such as language and religion, for example.

\subsection{Student migration model}

The model of Carling [14] shows the mechanism that generates migration. We will highlight in his model the moments that are directly related to the subject of our study - student migration. The origins of migration lie in the living conditions that underlie the desire for change, which, in turn, generates migration aspirations. Striving for change means recognising the need for change in life. Carling notes that this condition is also associated with the transition to independent adulthood [14]. The desire for change can be a positive force directed towards education. Migration infrastructure plays a vital role in

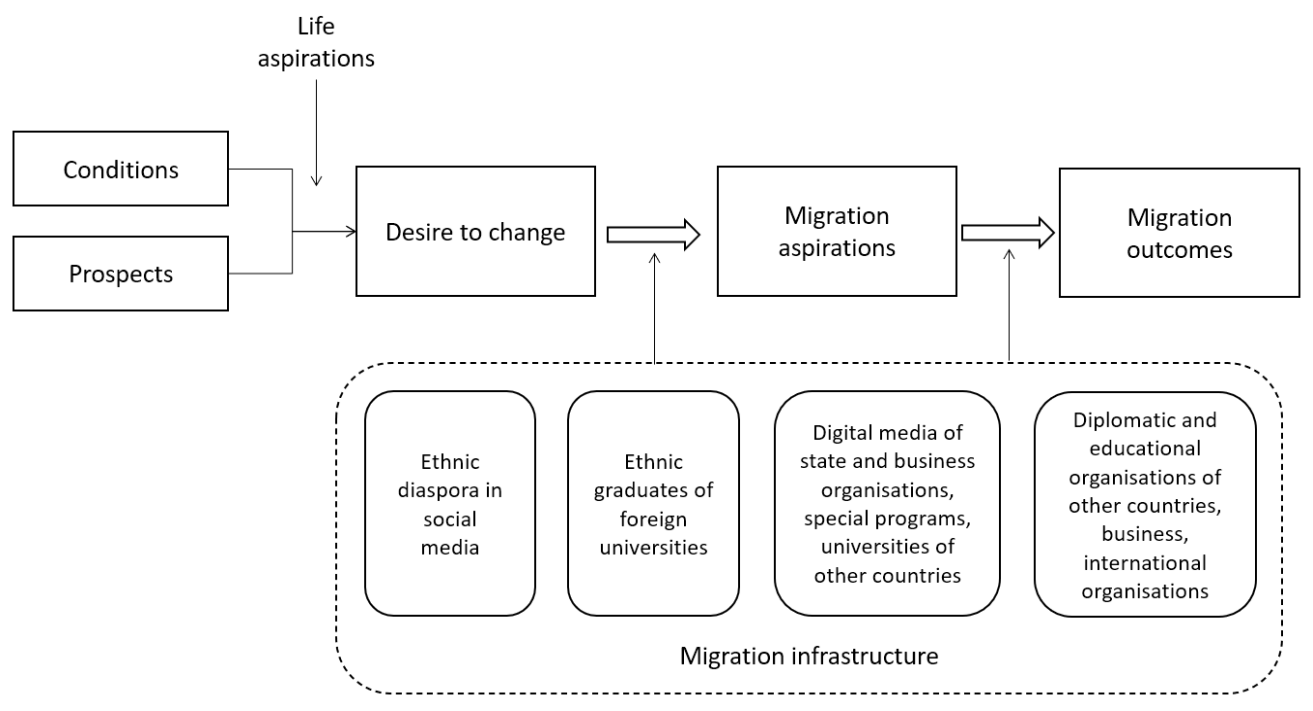

Figure 1 Student migration model.

Source: Created by the author based on [14] 
the migration process. It affects the likelihood that the willingness to change will be associated with migration and the success of moving to another country. Figure 1 shows a model of student migration. Unlike the Carling model, our model details the composition of the migration infrastructure that promotes student migration.

Interaction with ethnic diaspora via social media reduces risks. While studying in other countries, young people usually take an active part in student associations of their countries. They can help each other in their studies, organise events together, which contributes to intensive interaction between them. As a result, all their participants can accumulate much information about study conditions, residence, and employment prospects. Furthermore thus, they can provide those young compatriots who are analysing the possibility of studying at a foreign university with a rich source of insider knowledge about migration, which is discrete and unofficial [12].

\section{CONCLUSIONS}

The rapid development of digital media, including social media and messengers, contributed to creating new interaction channels during migration, leading to the simplification of contacts. This, in turn, facilitates migration. These statements are also valid for student migration. Young people actively use smartphones, social media and messengers. The ability to obtain information from ethnic, linguistic and religious diasporas plays a vital role in reducing migration risks. Interaction with them through digital media has become much easier. Graduates of foreign universities are an essential part of these diasporas and have valuable informal knowledge about education, residence and employment opportunities in the country they studied. A study conducted with the participation of RUDN international students confirms these conclusions.

\section{ACKNOWLEDGMENTS}

This paper has been supported by the RUDN University Strategic Academic Leadership Program.

\section{REFERENCES}

[1] O. Bracht, C. Engel, K. Janson, A. Over, H. Schomburg, U. Teichler, The Professional Value of ERASMUS Mobility, Kassel: International Centre for Higher Education Research, 2006.

[2] UNESCO Institute for Statistics official website. Retrieved from: http://uis.unesco.org/en/topic/higher-education

[3] M. Chankseliani, Four rationales of HE internationalisation: Perspectives of UK universities on attracting students from former Soviet countries,
Journal of Studies in International Education, 2007. DOI: https://doi.org/10.1177/1028315317725806

[4] A. Mihi-Ramirez, V. Kumpikaite, Economics reason of migration from students', Procedia - Social and Behavioural Sciences 109 (2014) 522-526.

[5] I. Hidayati, Social media and migration decisionmaking processes of Indonesian highly skilled migrant in the Middle East countries, Journal of Humanities and Social Studies 4(2) (2020) 141-145. DOI: https://doi.org/10.33751/jhss.v4i2.2459

[6] D. Massey, et al. Theories of International Migration: A Review and Appraisal, Population and Development Review 19(3) (1993) 432-449.

[7] J. Umblijs, The effect of networks and risk attitudes on migration dynamics, IMI Working Papers Series, No. 54, 2012. Retrieved from: https://www.migrationinstitute.org/publications/wp $\underline{-54-12}$

[8] A. Arefiev, Export of Russian educational services: Statistical Collection, Issue 10, Ministry of Science and Higher Education of the Russian Federation. M., Pushkin State Russian Language Institute, 2020. $557 \mathrm{p}$.

[9] Facts and Figures, January 2021, RUDN University official website. Retrieved from: https://eng.rudn.ru/u/www/files/about_rudn/inform ation-sheet_2021.pdf

[10] S. Spyratos, M. Vespe, F. Natale, W. Ingmar, E. Zagheni, M. Rango, Migration Data using Social Media: a European Perspective, EUR 29273 EN, Publications Office of the European Union, Luxembourg, 2018.2 DOI: https://doi.org/10.2760/964282

[11] Rosstat, Federal State Statistics Service of Russia official website. Retrieved from: https://rosstat.gov.ru/

[12] R. Dekker, G. Engbersen, How social media transform migrant networks and facilitate migration, Global Networks-a Journal of Transnational Affairs 14 (2014) 401-418.

[13] C. Audebert \& M. K. Dora1 (Eds.), Migration in A Globalised World: New Research Issues and Prospects, Amsterdam University Press, 2010, Retrieved from: http://www.jstor.org/stable/j.ctt46mwxq

[14] J. Carling, 'How Does Migration Arise?', in McAuliffe, M. and M. Klein Solomon (Conveners), Ideas to Inform International Cooperation on Safe, Orderly and Regular Migration, IOM: Geneva, $2017 . \quad$ Retrieved from: https://publications.iom.int/system/files/pdf/how_d oes_migration_arise.pdf 